\title{
HUBUNGAN PENGGUNAAN AIR BERSIH DAN JAMBAN KELUARGA DENGAN KEJADIAN DIARE PADA BALITA
}

\author{
Hamzah B ${ }^{1}$, St. Rahmawati Hamzah ${ }^{2}$ \\ Fakultas Ilmu Kesehatan, Institut Kesehatan dan Teknologi Graha Medika ${ }^{1,2}$ \\ hamzahbskm@gmail.com¹, rahmahamzah94@gmail.com²
}

\begin{abstract}
Diarrhea is still a health problem in the world, there are about 2 million cases of diarrhea worldwide every year, and 1,9 million children under five years die from diarrhea every year. Diarrhea in Indonesia is an endemic disease and it is very potential for extraordinary events to occur. Diarrhea was the 3rd highest infectious disease in North Sulawesi in 2018 with 20.982 cases in all age groups and 7.795 cases in children under five years. This study aims to analyze the relationship between the use of clean water and the use of latrines with the incidence of diarrhea in children under five years in Gogagoman Village, Kotamobagu. This study used a cross sectional study design with a total sample of 130 children under five years. The subjects of this study were mothers or caregivers of children under five years. The sampling technique used is simple random sampling. The data collection instrument used a questionnaire and an observation sheet. The data were then analyzed by univariate and bivariate using chi square test. The results showed that there was a relationship between the use of clean water $(p=0,036<0,05)$ and the use of latrines $(p=0,000<0,05)$ with the incidence of diarrhea in children under five years in Gogagoman Village. The conclusion of this study shows that children under five years suffering from diarrhea are associated with the use of clean water and the use of family latrines that do not meet health requirements.
\end{abstract}

\section{Keywords $\quad$ : Children Under Five Years, Diarrhea, Use of Clean Water, Use of Latrines}

\begin{abstract}
ABSTRAK
Diare masih menjadi masalah kesehatan di dunia, ada sekitar 2 juta kasus diare di seluruh dunia setiap tahun, dan 1,9 juta anak dibawah lima tahun meninggal karena diare setiap tahun. Penyakit diare di Indonesia merupakan penyakit yang endemis dan sangat potensial sekali terjadi Kejadian Luar Biasa (KLB). Diare merupakan 3 penyakit menular yang paling tinggi di Sulawesi Utara tahun 2018 dengan jumlah kasus sebanyak 20.982 pada semua kelompok umur dan sebanyak 7.795 kasus pada balita. Penelitian ini bertujuan untuk menganalisis hubungan penggunaan air bersih dan penggunaan jamban dengan kejadian diare pada balita di Kelurahan Gogagoman Kotamobagu. Penelitian ini menggunakan rancangan cross sectional study dengan jumlah sampel sebanyak 130 balita. Subjek penelitian ini adalah ibu atau pengasuh dari balita. Teknik penarikan sampel yang digunakan adalah simple random sampling. Instrumen pengumpulan data menggunakan kuesioner dan lembar observasi. Data selanjutnya dianalisis secara univariat dan bivariat dengan menggunakan uji chi square. Hasil penelitian menunjukkan bahwa ada hubungan penggunaan air barsih $(\mathrm{p}=0,036<0,05)$ dan penggunaan jamban $(\mathrm{p}=0,000<0,05)$ dengan kejadian diare pada balita di Kelurahan Gogagoman. Kesimpulan hasil penelitian ini menunjukkan bahwa balita yang menderita diare berhubungan dengan penggunaan air bersih dan penggunaan jamban keluarga yang tidak memenuhi syarat kesehatan.
\end{abstract}

Kata Kunci : Balita, Diare, Penggunaan Air Bersih, Penggunaan Jamban

\section{PENDAHULUAN}

Diare masih menjadi masalah kesehatan di dunia, termasuk di Indonesia. Kejadian Luar Biasa (KLB) Diare yang terjadi pada tahun 2017 tercatat sebanyak 21 kali yang tersebar di 12 provinsi dan 17 kabupaten/kota dengan jumlah penderita 1725 orang dan kematian sebanyak 34 orang (CFR 1,97\%) (Kemenkes RI, 2019).

Menurut data World Health Organization (WHO) tahun 2013, setiap tahunnya terdapat sekitar 1,7 miliar kasus 
penyakit diare pada anak, dengan angka kematian sekitar 760.000 balita di seluruh dunia. Bahkan angka ini lebih besar dibandingkan dengan gabungan angka kematian balita karena AIDS, malaria dan campak. Kasus diare dilaporkan sebanyak $78 \%$ terjadi di Afrika dan wilayah Asia Tenggara (WHO, 2013).

Penyakit diare di Indonesia merupakan penyakit yang endemis dan sangat potensial sekali terjadi Kejadian Luar Biasa (KLB) yang sering disertai dengan kematian. Data menunjukkan telah terjadi KLB diare setiap tahun dari tahun 2013 sampai 2016 dengan disertai peningkataan CFR 1,08\%-3,04\%, angka ini belum sesuai dengan yang diharapkan $<1 \%$. Jumlah kasus diare di Indoensia tahun 2018 sekitar 1,5 juta dengan persentasi kasus yang ditangai hanya $37,88 \%$ pada balita dan $58,20 \%$ pada semua kelompok umur. (Kemenkes RI, 2019).

Berdasarkan laporan STP berbasis puskesmas yang dikirimkan oleh puskesmas dan diolah di kabupaten/kota, maka penyakit influensa, hipertensi, dan diare merupakan 3 penyakit menular yang paling tinggi pada tahun 2018 dengan jumlah kasus sebanyak 20.982 pada semua kelompok umur dan sebanyak 7.795 kasus pada balita (Riskesdas, 2018). Jumlah penemuan kasus diare di Kotamobagu tahun 2019 masih cukup tinggi sekitar 1.301 kasus dengan presentasi kasus yang ditangani hanya $29 \%$ pada balita dan $54,7 \%$ untuk semua kelompok umur (Dinkes Kotamobagu, 2020).

Proses terjadinya diare pada balita dipengaruhi oleh beberapa faktor, yaitu faktor host, faktor agent, dan faktor environment. Faktor host terdiri dari karakteristik anak (umur, jenis kelamin, ASI eksklusif, imunisasi, dan status gizi), karakteristik ibu (umur, pendidikan, dan status pekerjaan), dan perilaku ibu (pengetahuan, sikap, dan tindakan). Faktor agent terdiri dari infeksi bakteri, virus, dan parasit, keracunan serta alergi (Rohmah \& Syahrul, 2017). Faktor environment yang berpengaruh terhadap kejadian diare diantaranya penyediaan air bersih, penggunaan jamban keluarga, pengelolaan sampah, sanitasi makanan dan kebiasaan mencuci tangan masyarakat (Setiyabudi \& Setyowati, 2016).

Faktor lingkungan yang dapat mempengaruhi kejadian diare pada balita adalah penggunaan air bersih dan jamban sehat keluarga. Air yang tercemar dapat mengandung banyak bakteri sehingga tidak memenuhi syarat kesehatan. Penggunaan air bersih harus berasal dari sumber air yang bersih (tidak berasa, tidak berbau, tidak berwarna) hal ini berhubungan erat dengan penyakit diare. Secara umum bakteri yang dapat menyebabkan diare dapat ditularkan melalui fecal oral (Rohmah \& Syahrul, 2017).

Pembuangan tinja yang tidak sesuai dengan syarat kesehatan dan sembarangan dapat mengakibatkan kontaminasi pada air, tanah, atau menjadi sumber infeksi, dan akan mendatangkan bahaya bagi kesehatan (Kasman \& Ishak, 2020). Tinja yang tidak ditampung dan diolah secara tertutup akan dapat terjangkau oleh vektor penyebab penyakit diare yang kemudian secara tidak langsung akan mencemari makanan atau minuman. Hal ini yang menjadi penyebab diare pada balita tidak dapat dipisahkan dari kebiasaan hidup sehat setiap anggota keluarga, terutama ibu (Mafazah, 2013).

Penelitian yang dilakukan di wilayah kerja Puskesmas Karanganyar Kabupaten Pekalongan dengan 64 responden, menemukan bahwa ada hubungan yang bermakna antara kondisi sarana air bersih dengan kejadian diare pada balita dengan nilai $p$ value $=0,022$ (Samiyati et al., 2019). Penelitian lain yang dilakukan di Kecamatan Sindue Kabupaten Donggala dengan 94 responden, menemukan terdapat hubungan yang signifikan antara penggunaan jamban dengan kejadian diare pada anak balita ( $p$ value $=0,003$ ) (Ifandi, 2017). 
Studi pendahuluan yang dilakukan di Kelurahan Gogagoman kasus diare pada balita masih mendominasi kasus terbanyak Januari-September 2020 dengan 98 kasus, disusul ISPA/Batuk sebanyak 74 kasus dan alergi sebanyak 46 kasus. Hasil wawancara dan observasi diperoleh bahwa keasadaran keluarga terutama pada ibu untuk melakukan perilaku hidup bersih dan sehat masih rendah (58\%) terkait dengan kebiasaan mencuci tangan dengan sabun dan air mengalir, penggunaan air bersih, penggunaan jamban sehat, pengelolaan sampah, sistem pengolahan air limbah.

Angka kejadian diare pada balita yang masih tinggi diduga bukan hanya dipengaruhi oleh faktor pengetahuan dan sikap ibu terhadap pencegahan diare, akan tetapi dipengaruhi oleh faktor lingkungan yang terkait dengan penggunaan air bersih dan penggunaan jamban keluarga, sehingga tujuan penelitian ini adalah untuk menganalisis hubungan penggunaan air bersih dan penggunaan jamban sehat dengan kejadian diare pada balita di Kelurahan Gogagoman Kotamobagu.

\section{METODE}

Jenis penelitian yang digunakan observasional analitik dengan rancangan cross sectional, yaitu suatu penelitian yang digunakan untuk mempelajari hubungan antar penggunaan air bersih dan penggunaan jamban sehat dengan kejadian diare pada balita dengan cara pendekatan observasional dimana pengumpulan data dilakukan sekaligus pada waktu yang bersamaan.

Penelitian ini dilaksanakan di Kelurahan Gogagoman Kota Kotamobagu Provinsi Sulawesi Utara. Penelitian ini dilaksanakan pada bulan Oktober 2020 dengan populasi semua balita yang tercatat sebagai warga Kelurahan Gogagoman sebanyak 208 balita. Sampel pada penelitian ini adalah sebagian dari populasi baik yang menderita diare dan tidak menderita diare. Penentuan Besar sampel menggunakan rumus Lemeshow (1977).
Berdasarkan hasil perhitungan menggunakan rumus tersebut, maka diperoleh besar sampel dalam penelitian ini sebanyak 130 responden.

Subjek pada penelitian adalah ibu atau pengasuh dengan balita yang memenuhi kriteria inklusi Ibu atau pengasuh yang memiliki balita yang berdomisili di Kelurahan Gogagoman dapat berkomunikasi dengan baik dan bersedia menjadi responden.

Teknik penarikan sampel pada penelitian ini menggunakan teknik pengambilan sampel secara simple random sampling yang memberikan kesempatan yang sama kepada semua anggota populasi untuk ditetapkan sebagai anggota sampel. Variabel dependen pada penelitian ini adalah kejadian diare pada balita dan variabel independen pada penelitian ini adalah penggunaan air bersih dan penggunaan jamban.

Data primer dikumpulkan dengan menggunakan kuesioner dan lembar observasi berupa data/informasi terkait penggunaan air bersih dan penggunaan jamban responden. Data sekunder berupa data kunjungan pasien balita baik yang diare maupun tidak diare di Puskesmas Gogagoman periode Januari-Juni 2020. Data selanjutnya dianalisis secara univariat untuk melihat distribusi frekuensi masingmasing variabel dan analisis bivariat untuk menguji hubungan antara variabel independen dengan variabel dependen menggunakan uji chi square $\alpha=0,05$.

\section{HASIL}

Karakteristik responden berdasarkan umur, tingkat pendidikan dan pekerjaan dapat dilihat pada tabel berikut ini:

\begin{tabular}{|c|c|c|}
\hline \multicolumn{3}{|c|}{$\begin{array}{l}\text { Tabel 1. Distribusi Frekuensi Karakteristik } \\
\text { Responden Berdasarkan Umur, } \\
\text { Tingkat Pendidikan dan Pekeriaan }\end{array}$} \\
\hline Karakteristik Responden & Frekuensi & $\%$ \\
\hline \multicolumn{3}{|l|}{ Umur (tahun) } \\
\hline$<20$ & 29 & 22,3 \\
\hline $21-29$ & 57 & 43,8 \\
\hline $30-39$ & 34 & 26,2 \\
\hline$>40$ & 10 & 7,7 \\
\hline
\end{tabular}




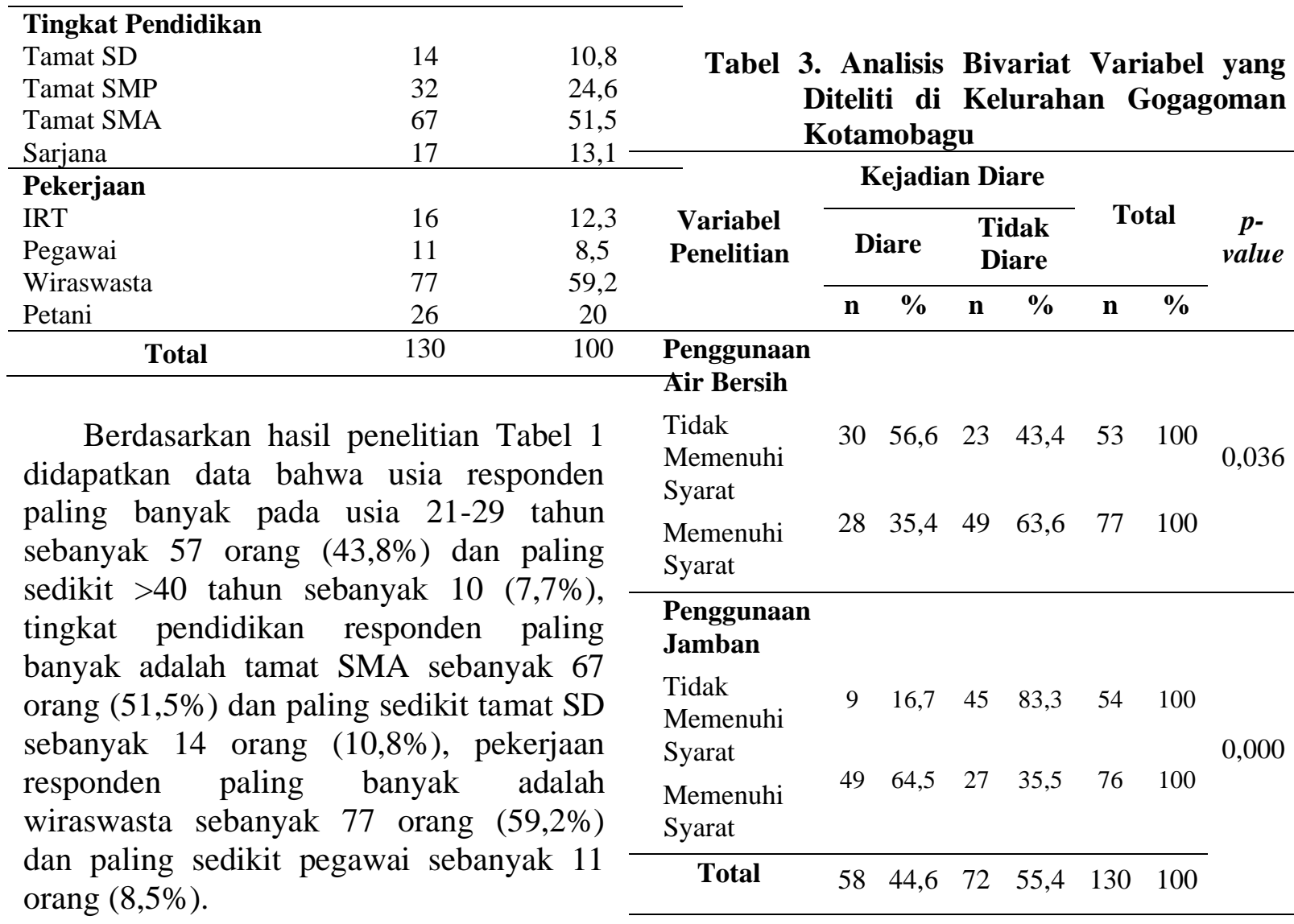

Tabel 2. Analisis Univariat Variabel yang Diteliti di Kelurahan Gogagoman Kotamobagu

\begin{tabular}{lcc}
\hline \multicolumn{1}{c}{ Variabel Penelitian } & Frekuensi & \% \\
\hline Penggunaan Air Bersih & & \\
Tidak Memenuhi Syarat & 53 & 40,8 \\
Memenuhi Syarat & 77 & 59,2 \\
\hline Penggunaan Jamban & & \\
Tidak Memenuhi Syarat & 54 & 41,5 \\
Memenuhi Syarat & 76 & 58,5 \\
\hline Kejadian Diare & & \\
Diare & 58 & 44,6 \\
Tidak Diare & 72 & 55,4 \\
\hline \multicolumn{1}{c}{ Total } & 130 & 100 \\
\hline
\end{tabular}

Hasil penelitian Tabel 2 menunjukkan bahwa penggunaan air bersih responden yang tidak memenuhi syarat kesehatan sebanyak 40,8\%, sedangkan yang memenuhi syarat kesehatan sebanyak $59,2 \%$. Penggunaan jamban yang tidak memenuhi syarat kesehatan sebanyak $41,5 \%$, sedangkan yang memenuhi syarat kesehatan sebanyak 58,5\%. Dan terdapat $44,6 \%$ responden yang memiliki balita menderita diare sedangkan yang tidak diare sebanyak $55,4 \%$.
Hasil penelitian Tabel 3 menunjukkan bahwa dari 53 responden yang menggunakan air bersih tidak memenuhi syarat kesehatan terdapat $30(56,6 \%)$ yang mempunyai balita menderita diare dan terdapat $23(43,4 \%)$ responden yang mempunyai balita tidak menderita diare, sedangkan dari 77 responden yang menggunakan air bersih memenuhi syarat kesehatan terdapat $49(63,6 \%)$ responden yang mempunyai balita menderita diare dan terdapat $28(35,4 \%)$ responden yang mempunyai balita tidak menderita diare.

Hasil uji chi square antara variabel penggunaan air bersih dengan kejadian diare pada balita diperoleh nilai $p$ value $=$ $0,036(\mathrm{p}<0,05)$ maka $\left(\mathrm{H}_{0}\right.$ ditolak) yang artinya ada hubungan penggunaan air bersih dengan kejadian diare pada balita.

Selanjutnya dari 54 responden yang menggunakan jamban tidak memenuhi syarat kesehatan terdapat $9(16,7 \%)$ yang mempunyai balita menderita diare dan terdapat $45(83,3 \%)$ responden yang mempunyai balita tidak menderita diare, 
sedangkan dari 76 responden yang menggunakan jamban memenuhi syarat kesehatan terdapat $27(35,5 \%)$ responden yang mempunyai balita tidak menderita diare dan terdapat $49(64,5 \%)$ responden yang mempunyai balita menderita diare.

Hasil uji chi square antara variabel penggunaan jamban dengan kejadian diare pada balita diperoleh nilai $p$ value $=0,000$ ( $\mathrm{p}<0,05)$ maka $\left(\mathrm{H}_{0}\right.$ ditolak) yang artinya ada hubungan penggunaan jamban dengan kejadian diare pada balita.

\section{PEMBAHASAN}

\section{Hubungan Penggunaan Air Bersih dengan Kejadian Diare pada Balita}

Keadaan air yang digunakan seharihari baik langsung maupun tidak langsung sangat mempengaruhi kesehatan pada manusia, maka penggunaan air dalam kehidupan sehari - hari harus dapat memenuhi syarat kesehatan untuk mencegah kemungkinan timbulnya berbagai macam penyakit. Air yang tidak memenuhi persyaratan kesehatan merupakan media penularan penyakit seperti penyakit diare (Kemenkes RI, 2011).

Didapatkan bahwa dari 53 responden yang menggunakan air bersih tidak memenuhi syarat kesehatan terdapat $56,6 \%$ yang mempunyai balita menderita diare. Hal ini disebabkan penyakit diare merupakan penyakit yang disebabkan oleh multifaktor, responden yang menggunakan air bersih yang sudah memenuhi syarat kesehatan, namun masih memiliki balita yang menderita diare. Hal ini bisa disebabkan masih ada responden yang mempunyai kebiasaan buruk dalam hal mencuci tangan dengan air bersih dan sabun sebanyak $(68,1 \%)$ dan penggunaan jamban yang tidak memenuhi syarat kesehatan sebanyak (41,5\%).

Sedangkan dari 77 responden yang menggunakan air bersih yang memenuhi syarat kesehatan, terdapat $35,4 \%$ responden yang memiliki balita menderita diare. Hal ini bisa disebabkan responden masih menggunakan air bersih yang tidak memenuhi syarat kesehatan seperti air yang berbau $26,1 \%$, berasa sebanyak $14,6 \%$ dan berwarna sebanyak $3,5 \%$, serta masih ada responden sebanyak $0,4 \%$ yang tidak memasak air sampai mendidih sebelum dikonsumsi. Hasil observasi menunjukkan ada beberapa responden yang terbiasa menampung air untuk keperluan minum dan masak dalm wadah yang tidak tertutup rapat dan jarak antara sumber air bersih dengan jamban keluarga kurang dari 10 meter.

Salah satu upaya kegiatan pencegahan diare yang benar dan efektif adalah dengan menggunakan air bersih, karena sebagian besar bakteri penyebab diare ditularkan melalui jalur fecal oral bakteri tersebut dapat menular melalui mulut, cairan atau benda yang tercemar dengan tinja, misalnya air minum, jari-jari tangan, makanan yang disiapkan dalam panci yang dicuci dengan air yang tercemar (Kemenkes RI, 2011).

Penelitian ini menunjukkan ada hubungan penggunaan air bersih dengan kejadian diare pada balita di Kelurahan Gogagoman Kotamobagu dengan nilai $p$ value $=0,036$. Hasil penelitian ini sejalan dengan penelitian yang dilakukan di Desa Mala Kecamatan Manganitu dengan jumlah sampel sebanyak 73 orang balita, menemukan hubungan yang bermakna antara penyediaan sarana air bersih dengan kejadian diare pada balita, dengan memperoleh nilai $p=0,002$ (Katiandagho \& Darwel, 2019). Penelitian yang dilakukan di Kecamatan Karangeja Kabupaten Purbalingga dengan jumlah sampel 77 responden, menemukan ada hubungan antara penggunaan air bersih dengan kejadian penyakit diare $(p=0,019)$, nilai Koefisien Kontingensi (CC) sebesar 0,286 menunjukkan hubungan yang rendah atau lemah antara penggunaan air bersih dengan kejadian penyakit diare (Irawan, 2013).

Sumber air bersih masyarakat harus memenuhi syarat kesehatan seperti sumur gali harus mempunyai dinding dan bibir 
sumur, mempunyai saluran pembuangan air limbah, terletak \pm 10 meter dari tempat sampah dan jamban keluarga, Jika ditinjau dari sudut ilmu kesehatan masyarakat, penyediaan sumber air bersih harus dapat memenuhi kebutuhan masyarakat karena persediaan air bersih yang terbatas memudahkan timbulnya penyakit di masyarakat (Mokosandib et al., 2017).

\section{Hubungan Penggunaan Jamban dengan Kejadian Diare pada Balita}

Tinja merupakan hasil metabolisme yang harus dibuang pada tempat yang aman yaitu jamban. Pembuangan tinja secara tidak baik dan sembarangan dapat mengakibatkan kontaminasi pada air, tanah, atau menjadi sumber infeksi, dan akan mendatangkan bahaya bagi kesehatan, serta dapat meningkatkan angka kesakitan dari penyakit diare karena penyakit tersebut tergolong waterborne disease yang mudah menular (Notoatmodjo, 2011).

Didapatkan bahwa dari 54 responden yang menggunakan jamban tidak memenuhi syarat kesehatan terdapat $16,7 \%$ yang mempunyai balita menderita diare. Hal ini disebabkan penyakit diare merupakan penyakit yang disebabkan oleh multifaktor, responden yang menggunakan jamban yang sudah memenuhi syarat kesehatan, namun masih memiliki balita yang menderita diare. Hal ini bisa disebabkan masih ada responden yang menggunakan air bersih tidak memenuhi syarat kesehatan sebanyak 40,8\% dan ibu yang mempunyai kebiasaan buruk dalam hal mencuci tangan dengan air bersih dan sabun sebanyak $68,1 \%$.

Sedangkan dari 76 responden yang menggunakan jamban yang tidak memenuhi syarat kesehatan, terdapat $64,5 \%$ responden yang memiliki balita menderita diare. Berdasarkan hasil wawancara dan observasi ternyata dari 130 responden yang diwawancarai terdapat 122 $(93,8 \%)$ yang memiliki jamban dan sebanyak $8(6,2 \%)$ yang tidak memiliki jamban. Dari 122 responden yang memiliki jamban terdapat 23,7\% responden yang tidak menggunakan jamban sebagai tempat untuk buang fases, dan masih ada sebanyak $17,6 \%$ responden yang memiliki jamban yang berjarak kurang dari 10 meter dari sumber air bersih, serta masih ada responden yang mempunyai perilaku membuang tinja balita di sekitar rumah sebanyak 8,4\% .

Penelitian ini menunjukkan ada hubungan penggunaan jamban dengan kejadian diare pada balita di Kelurahan Gogagoman Kotamobagu dengan nilai $p$ value $=0,000$. Hasil penelitian ini sejalan dengan penelitian yang dilakukan di wilayah kerja Puskesmas Meuraxa dengan jumlah sampel 59 balita, menemukan ada hubungan antara penggunaan jamban dengan angka kejadian diare pada balita di wilayah kerja Puskesmas Meuraxa dengan nilai ( $p$ value $0,000<0,05$ ) (Lidiawati, 2016). Penelitian lain yang dilakukan di Puskesmas Martapura Barat dengan jumlah sampel 76 responden ibu yang memiliki balita, menemukan ada hubungan antara penggunaan jamban sehat dengan kejadian diare ( $p$ value $0,049<\alpha=0,05$ ) (Irianty et al., 2018). Penelitian yang dilakukan Kelurahan Saung Naga wilayah kerja Puskesmas Tanjung Agung Baturaja Barat dengan jumlah sampel sebanyak 159 balita, menemukan ada hubungan yang signifikan antara penyediaan air bersih dengan kejadian diare pada balita dengan $p$ value $=0,001$ (Meliyanti, 2016).

Penyakit diare dapat ditularkan melalui kotoran manusia, semua orang dalam keluarga harus menggunakan jamban dan jamban harus dalam keadaan bersih agar terhindar dari serangga yang dapat menularkan atau memindahkan penyakit pada makanan. Rumah tangga yang mempunyai kebiasaan membuang tinja yang tidak memenuhi syarat meningkatkan risiko diare pada balita sebesar 2 kali lipat dibandingkan dengan rumah tangga yang mempunyai kebiasaan membuang tinja sesuai aturan (Rohmah, 2016). 
Syarat jamban sehat untuk keluarga adalah tidak mengotori permukaan tanah disekitar jamban, tidak mencemari air permukaan disekitar jamban, tidak mengotori air tanah, tidak menjadi tempat berkembang biaknya serangga dan binatang pembawa bibit penyakit, dan tidak menimbulkan bau yang tidak sedap (Kemenkes RI, 2013). Penggunaan jamban yang tidak sehat akan menyebabkan lingkungan sekitar rumah menjadi buruk sehingga hal ini akan memudahkan kuman penyakit diare untuk menginfeksi manusia. Intervensi perilaku menjadi penting untuk dilakukan untuk memberikan pemahaman kepada masyarakat untuk memanfaatkan jamban keluarga sesuai dengan syarat kesehatan (Fithriyana, 2017).

\section{KESIMPULAN}

Berdasarkan hasil penelitian dapat disimpulkan bahwa faktor lingkungan mempunyai peran penting dalam meningkatkan kejadian diare pada balita. Balita yang menderita diare berhubungan dengan penggunaan air bersih keluarga yang tidak memenuhi syarat kesehatan dan penggunaan jamban keluarga yang tidak memenuhi syarat kesehatan. Penggunaan air bersih dan jamban keluarga yang tidak memenuhi syarat kesehatan mengakibatkan faktor penyebab diare lebih cepat menginfeksi balita.

\section{UCAPAN TERIMA KASIH}

Peneliti mengucapkan terima kasih kepada Pimpinan Yayasan Bogani yang telah memberikan dukungan sehingga penelitian ini bisa terlaksana dengan baik. Kepada Rektor dan Ketua LPPM Institut Kesehatan dan Teknologi Graha Medika yang telah memberikan motivasi dan dukungan moral kepada peneliti didalam pelaksanaan penelitian. Kepada Pemerintah Kota Kotamobagu dalam hal ini Kepala Puskesmas Gogagoman, Lurah Gogagoman yang telah memberikan izin pelaksanaan penelitian. Terima kasih juga kepada responden dan seluruh masyarakat
Kelurahan Gogagoman yang ikut berpartisipasi didalam penelitian ini.

\section{DAFTAR PUSTAKA}

Dinkes Kotamobagu. (2020). Profil Kesehatan Kotamobagu Tahun 2019. Kotamobagu: Dinas Kesehatan Kotamobagu.

Fithriyana, R. (2017). Hubungan Lingkungan Rumah dengan Kejadian Diare pada Balita di Desa Suka Damai Wilayah Kerja Puskesmas Ujung Batu Kabupaten Rokan Hulu. PREPOTIF: Jurnal Kesehatan Masyarakat, 1(1), 41-49.

Ifandi, S. (2017). Hubungan Penggunaan Jamban dan Sumber Air dengan Kejadian Diare pada Balita di Kecamatan Sindue. Afiasi: Jurnal Kesehatan Masyarakat, 2(2), 38-44.

Irawan, A. Y. (2013). Hubungan antara aspek kesehatan lingkungan dalam phbs rumah tangga dengan kejadian penyakit diare di kecamatan karangreja tahun 2012. Unnes Journal of Public Health, 2(4).

Irianty, H., Hayati, R., \& Riza, Y. (2018). Hubungan Perilaku Hidup Bersih dan Sehat (PHBS) dengan kejadian diare pada balita. PROMOTIF: Jurnal Kesehatan Masyarakat, 8(1), $1-10$.

Kasman, K., \& Ishak, N. I. (2020). Kepemilikan Jamban Terhadap Kejadian Diare pada Balita di Kota Banjarmasin. Jurnal Publikasi Kesehatan Masyarakat Indonesia, 7(1), 28-33.

Katiandagho, D., \& Darwel, D. (2019). Hubungan Penyediaan Air Bersih dan Jamban Keluarga Dengan Kejadian Diare Pada Balita Di Desa Mala Kecamatan Manganitu Tahun 2015. Jurnal Sehat Mandiri, 14(2), 64-78.

Kemenkes RI. (2011). Situasi diare di Indonesia. Buletin Jendela Data Dan Informasi Kesehatan, 2(2), 1-6. Jakarta: Kementrian Kesehatan RI. 
Kemenkes RI. (2013). Riset Kesehatan Dasar 2013. Jakarta: Badan Penelitian dan Pengembangan Kesehatan.

Kemenkes RI. (2019). Profil Kesehatan Indonesia Tahun 2018. Jakarta: Kementrian Kesehatan RI.

Lidiawati, M. (2016). Hubungan sanitasi lingkungan dengan angka kejadian diare pada balita di wilayah kerja Puskesmas Meuraxa tahun 2016. Serambi Saintia: Jurnal Sains Dan Aplikasi, 4(2).

Mafazah, L. (2013). Ketersediaan sarana sanitasi dasar, personal hygiene ibu dan kejadian diare. KEMAS: Jurnal Kesehatan Masyarakat, 8(2).

Meliyanti, F. (2016). Faktor-faktor yang berhubungan dengan kejadian diare pada balita. Jurnal Aisyah: Jurnal Ilmu Kesehatan, 1(2), Hal-09.

Dinkes Kotamobagu. (2020). Profil Kesehatan Kotamobagu Tahun 2019. Kotamobagu: Dinas Kesehatan Kotamobagu.

Fithriyana, R. (2017). Hubungan Lingkungan Rumah dengan Kejadian Diare pada Balita di Desa Suka Damai Wilayah Kerja Puskesmas Ujung Batu Kabupaten Rokan Hulu. PREPOTIF: Jurnal Kesehatan Masyarakat, 1(1), 41-49.

Ifandi, S. (2017). Hubungan Penggunaan Jamban dan Sumber Air dengan Kejadian Diare pada Balita di Kecamatan Sindue. Afiasi: Jurnal Kesehatan Masyarakat, 2(2), 38-44.

Irawan, A. Y. (2013). Hubungan antara aspek kesehatan lingkungan dalam phbs rumah tangga dengan kejadian penyakit diare di kecamatan karangreja tahun 2012. Unnes Journal of Public Health, 2(4).

Irianty, H., Hayati, R., \& Riza, Y. (2018). Hubungan Perilaku Hidup Bersih dan Sehat (PHBS) dengan kejadian diare pada balita. PROMOTIF: Jurnal Kesehatan Masyarakat, 8(1), $1-10$.

Kasman, K., \& Ishak, N. I. (2020).
Kepemilikan Jamban Terhadap Kejadian Diare pada Balita di Kota Banjarmasin. Jurnal Publikasi Kesehatan Masyarakat Indonesia, 7(1), 28-33.

Katiandagho, D., \& Darwel, D. (2019). Hubungan Penyediaan Air Bersih dan Jamban Keluarga Dengan Kejadian Diare Pada Balita Di Desa Mala Kecamatan Manganitu Tahun 2015. Jurnal Sehat Mandiri, 14(2), 64-78.

Kemenkes RI. (2011). Situasi diare di Indonesia. Buletin Jendela Data Dan Informasi Kesehatan, 2(2), 1-6. Jakarta: Kementrian Kesehatan RI.

Kemenkes RI. (2013). Riset Kesehatan Dasar 2013. Jakarta: Badan Penelitian dan Pengembangan Kesehatan.

Kemenkes RI. (2019). Profil Kesehatan Indonesia Tahun 2018. Jakarta: Kementrian Kesehatan RI.

Lidiawati, M. (2016). Hubungan sanitasi lingkungan dengan angka kejadian diare pada balita di wilayah kerja Puskesmas Meuraxa tahun 2016. Serambi Saintia: Jurnal Sains Dan Aplikasi, 4(2).

Mafazah, L. (2013). Ketersediaan sarana sanitasi dasar, personal hygiene ibu dan kejadian diare. KEMAS: Jurnal Kesehatan Masyarakat, 8(2).

Meliyanti, F. (2016). Faktor-faktor yang berhubungan dengan kejadian diare pada balita. Jurnal Aisyah: Jurnal Ilmu Kesehatan, 1(2), Hal-09.

Mokosandib, V., Rumajar, P. D., \& Suwarja, S. (2017). Penyediaan Air Bersih dan Jamban Keluarga Dengan Kejadian Diare pada Balita di Desa Betelen Kecamatan Tombatu Kabupaten Minahasa Tenggara. Jurnal Kesehatan Lingkungan, 7(2), $52-62$.

Notoatmodjo, S. (2011). Ilmu Kesehatan Masyarakat: Ilmu \& Seni. Jakarta: Rineka Cipta.

Riskesdas. (2018). Laporan Provinsi Sulawesi Utara Riskesdas 2018. 
Jakarta: Lembaga Penerbit Badan Litbang Kesehatan.

Rohmah, N. (2016). Hubungan Antara PHBS, Penggunaan Air Bersih, Dan Jamban Sehat Di Rumah Tangga Dengan Kejadian Diare Pada Balita Di Wilayah Kerja Puskesmas Sekardangan Kabupaten Sidoarjo. Skripsi. Surabaya, Universitas Airlangga.

Rohmah, N., \& Syahrul, F. (2017). Hubungan kebiasaan cuci tangan dan penggunaan jamban sehat dengan kejadian diare balita. Jurnal Berkala Epidemiologi, 5(1), 95-106.

Samiyati, M., Suhartono, S., \& Dharminto, D. (2019). Hubungan Sanitasi Lingkungan Rumah dengan Kejadian Diare pada Balita di Wilayah Kerja Puskesmas Karanganyar Kabupaten Pekalongan. Jurnal Kesehatan Masyarakat (e-Journal), 7(1), 388395.

Setiyabudi, R., \& Setyowati, V. (2016). Penyediaan air bersih, penggunaan jamban keluarga, pengelolaan sampah, sanitasi makanan dan kebiasaan mencuci tangan berpengaruh terhadap kejadian diare umur 15-50 th. MEDISAINS, 14(2).

WHO. (2013). Diarrhoeal disease. http://www.who.int/mediacentre/fact sheets/fs330/en/ 